sources that researchers rely on. The subject of the proposed article is The Paris Diary of Borys Lazarevsky, who was a Russian and Ukrainian fiction writer, a son of a famous Ukrainian historian Olexander Lazarevsky (1834-1902). The author's notes as a projection of the Parisian expatriate life are relevant in the context of these issues, including everything "denoted by a Ukrainian marker": reflections on Ukraine, assessments of certain events of life, culture and people related to them.

Purpose. The purpose of the article is to introduce the contents of The Paris Diary of B. Lazarevsky for 1927-1929 to the Ukrainian historiographic space. B. Lazarevsky kept diary notes throughout his life. There is a prevailing assertion that there are 60 volumes of such entries. The emigration period is represented only by the volume from 1924 to 1925, which is kept in the Russian State Archive of Literature and Art (Moscow) and an exemplar for 1927-1929. The last one from the time of its founding is still kept in the private collection of the family of I. Goncharenko.

Results. B. Lazarevskyj was a well-known figure in both Russian and Ukrainian immigrant communities. His name is often recorded in the Russian-speaking secular chronicle of Paris next to the names of the famous figures of culture. Thanks to his charisma, literary talent, public activity, personal relations B. Lazarevskyj received material assistance from the President and the Government of Czechoslovakia until 1930. He lived poorly, but he loved Paris: streets and parks, theatres and cinemas, transport and the press, he adored the Parisian lifestyle because of its publicity, a crowd of beautiful and uninhibited women, its leisure and communication.

Originality. For the first time the content of the diary entries for $1927-1929$ by B. Lazarevsky was partly analyzed in contemporary Ukrainian historiography.

Conclusion. Borys Lazarevsky's Diary for 1927-1929 (both his own manuscripts and his correspondence) is a valuable and important original source, the study, analysis and publication of the content of which will supplement contemporary Ukrainian historiography in the researches of Ukrainian emigration of the 20-30s of the twentieth century. We consider that the development of following areas are very promising: B. Lazarevsky's scientific and literary surroundings, his collaboration with the representatives of Ukrainian and Russian Paris emigration, the publication (for the first time) of their autographs; B. Lazarevsky's assessment of contemporary political, social and cultural changes (for example, events in Ukraine - from the UPR to the USSR and the RSFSR) and others. Sympathies and antipathies, subjective perception of people and events are always the most interesting when they are dealing with a bright and an extraordinary personality, and that is exactly our point of view about Borys Lazarevsky. Private, personal and creative are interlaced and integral in this personality.

Key words: The Lazarevsky family, Parisian Ukrainian emigration of the 1920s and 1930s, everydaylife Одержано редакцією 15.04 .2020

Прийнято до публікації 19.05.2020

\begin{abstract}
УДК 94 (477-22)«1929/1933»:316.647.5 (045) DOI: 10.31651/2076-5908-2020-1-109-118
\end{abstract}

\author{
MOTUZ Valeria, \\ Candidate of Sciences (History), Senior \\ Lecturer at the Department of Archeology \\ and Special Branches of Historical Science \\ Bohdan Khmelnytsky National University \\ of Cherkasy, \\ Orcid ID: 0000-0002-9974-7205 \\ e-mail: v.k.motuz@ukr.net
}

\title{
THE MANIFESTATIONS OF XENOPHOBIC SENTIMENTS OF THE PEASANTRY OF THE UKRAINIAN SSR DURING THE COMPLETE COLLECTIVIZATION
}

The article considers the problem of intolerance among the peasantry of the Ukrainian SSR during 1929 - 1933. The author concludes that during the relevant time the expressions of xenophobic attitudes in the environment the peasantry of the Ukrainian SSR were influenced by two key factors: primary tribalism and a specific form of ideology, with the help of which they found the strength in itself to fight "strangers".

Key words: continuous collectivization, peasantry of the Ukrainian SSR, xenophobia, workers-twenty five thousanders, appointees, rural activists. 
Before proceeding to the subject mentioned in this publication, it is necessary to define the concept of "xenophobia". Xenophobia is an expression of intolerance of someone or something alien, incomprehensible, unfamiliar, and therefore dangerous and hostile. This intolerance appears within ethnic, racial, social, denominational, cultural and other conflicts [1]. Being a sociopsychological phenomenon, it can be inherent in both collective and individual consciousness [2, 194].

Social sentiment is closely linked to the issue of cultural and historical self-identification of a social individual and is formed on the basis of motivational-value criteria and his/her perception of the world, which is divided into "friends" and "foes". Community members at different stages of their development tend to perceive and evaluate life phenomena through the prism of basic values and traditions of their own group, which acts as a standard or norm: "we" ("friends") is better than "they" ("foes").

In this case, the word "we" means the peasantry of the Ukrainian SSR during the period of complete collectivization (1929 - 1933). This concept will be considered from the point of view of belonging to the conservative for the relevant social category of the institute - peasant-owner (free landowner), that is a historically formed organizational and legal form of individual land use and local self-government in the Ukrainian rural area. The word "they" means all those who did not fit into the proper format and contributed to the final eradication of independent farmership from the Ukrainian countryside and to the establishment of collectivism in it. In most cases, these are people who were not directly involved in the rural community.

The actuality. The first thing that determines the relevance of this research topic, is its specificity, by which the issue of xenophobia is constantly in the spotlight of the world public, especially politicians, scientists and publicists. Another need for large-scale coverage of the issue of "friend-or-foe" in the environment the peasants of the Ukrainian SSR during the relevant period of the interwar time lies in the lack of research into it. In Ukrainian historiography, the topic, being a component of such issues as the socio-political sentiment and culture of everyday life of the peasantry of the Ukrainian SSR, which is viewed from different perspectives in numerous scientific publications of the above content, is presented in a fragmentary way. In fact, we see a lack of research that would aim at a complete reconstruction of the process of expression of xenophobic sentiments by the peasants of the Ukrainian SSR during 1929 - 1933, which prompted the author to write this article.

The purpose. The author of the article aims to theoretically substantiate the problem of xenophobic sentiment among the peasantry of the Ukrainian SSR during $1929-1933$.

The historiography of the question. On the basis of a comprehensive reflection of scientific works, which allows to find out the degree of research of the issue of xenophobic attitudes in the environment the peasants of the Ukrainian SSR during 1929 - 1933 and the nature of coverage of its key aspects, the author of the publication came to the conclusions that the scientific literature on the history the peasants of the Ukrainian SSR has no comprehensive scientific research on the outlined issue. However, this topic still found its reflection in the domestic historical science.

Scientific publications, to one degree or another, concerning the manifestation of xenophobic sentiments by the peasantry of the Ukrainian SSR within the specified period, include scientific works of V. Burda [18], Y. Danilieva [16; 24], G. Georgizov [4], N. Goncharova [7], Y. Guk [2], J. Irioglu [26], S. Kulchytsky [13; 19], O. Lysenko [17], V. Lozovy [8], V.Moskalenko [5], V. Petrenko [10], V. Ruban [23], V. Slivenko [28], V. Sukhonos [25], P. Trigub [21], V. Vasyliev [15], O. Vovk [9; 14], L. Yepik [6], and A. Trostogon [12] devoted to peasant resistance to collectivization, the use of city workers by Soviet power for the Sovietization of the Ukrainian SSR countryside, political moods and transformation of the traditional outlook of the Ukrainian SSR peasantry, socio-economic relations between the city and the countryside, features of the escalation of conflict in different fields of society, daily life of the Ukrainian SSR peasantry, coexistence of urban and rural cultures, dynamics of socio-political mood, the typology of rural activists' behavior, the perception of the Ukrainian SSR peasantry by the Bolsheviks and the Soviet authorities, the Soviet model of local self-government not that.

At the same time, special studies in which the manifestations of xenophobic sentiments of the peasantry of the Ukrainian SSR in 1929 - 1933 were comprehensively considered are absent 
today. However, various aspects of the relationship between the peasantry and Soviet power in all their diversity, both nationwide and in individual regions within the designated period, are presented in the scientific literature.

Presenting the main material. Stalin's supporters, applying the ancient practice of "divide and rule", which they elevated to the level of state policy, caused an aggravation of the opposition of workers to the peasantry $[3,125]$. This inevitably led to an increase in the binary antithesis of "friend or foe" among the peasantry of the Ukrainian SSR.

Not recognizing the majority of Bolshevik ideas and political aspirations, the Ukrainian peasantry thus blocked its path to the ruling party-Soviet structures. But even when their insignificant number nevertheless fell into the ranks of the Communist Party, their traditional, folk psychology came into conflict with Bolshevik rhetoric [4, 62].

In the minds of the peasantry of the Ukrainian SSR, a negative opinion firmly settled on the fact that, as always, they simply profit from their work, without giving them anything substantial in return. Whereas earlier the peasantry showed its discontent with the landowners, then during the continuous collectivization they outlined a new social competitor - urban workers, whose negative assessment was formed as a result of significant differences in the way of life. First of all, we are talking about the economic and cultural development of these two social groups [5, 22].

In accordance with the understanding of the peasantry of the Ukrainian SSR, the Soviet government, along with a loyal minority (proletariat), deliberately pursued anti-peasant politics. The oppression of the Ukrainian peasant, who had the characteristic features of family-economic egocentrism. As well as the constant attempts of the Soviet government to turn him into a collective farmer $[4,64]$, led to the destruction of the traditional way of his life, primarily the destruction of his self-awareness as an individual owner $[6,13]$.

In addition, in the peasant society of the Ukrainian SSR it was believed that the urban worker, unlike the peasant, had many privileges, enjoyed great socio-economic and political rights $[7 ; 8$, 93]. This was explained by the presentation of the Ukrainian peasantry of the city as "a place of accumulation of various human rubbish: parasites, loafers, who only do that, roam and commit atrocities". The peasantry believed that the proletariat received such a "cheerful and frivolous life" thanks to it. What exactly the peasant pays for her with his hard daily work. Equally important in strengthening peasant stereotypes regarding the city were the events associated with the introduction of continuous collectivization [9, 215].

During the policy of continuous collectivization, the Soviet government repeatedly sent its representatives, which included workers, to the Ukrainian village to facilitate the cause of its Sovietization.

In particular, at the November plenary session of the Central Committee of the All-Union Communist Party of Bolsheviks in 1929, the Soviet government, planning a collectivization of agriculture, initiated a mass sending of 25,000 workers (mainly communists) to work in the countryside permanently $[10,69]$.

Workers sent to a Ukrainian village not only headed the local authorities, but were also widely used by the Soviet authorities to psychological and physical pressure on the peasants, as well as to confiscate their personal property $[11,101]$. Therefore, officially it was the staff of assistants to the Soviet power in the village, which she used. De jure in organizing a collective form of production on a voluntary basis and helping the peasantry of the Ukrainian SSR in cultural and material terms $[12,136]$. De facto, in order to implement the state program for grain procurement and forced imposition of Ukrainian rural society, the majority of which were individual peasants, collective farms [13, 84].

The next business trip of 5,000 workers to work in a Ukrainian village and providing them with appropriate working conditions on the ground was discussed at a meeting of the Secretariat of the All-Ukrainian Central Executive Committee. This happened on January 1, 1930 and was indicated in "Protocol No. 39/432" [14, 57]. An important criterion in the selection of workers for work in the village was not their professional abilities. After all, they simply could not have been in people who were not specialists in agricultural production and were familiar with life in the village only in general terms. Applying this format of "quality selection", the Soviet government relied on obedient performers of their will $[14,58]$. 
The corresponding policy contributed to the aggravation of the contradictions between the proletariat and the Ukrainian peasantry $[14,61]$. In particular, the attitude of the peasants towards urban workers during the of the first five-year plan influenced by factors such as non-Ukrainian origin of the proletarians, them product harvesting working trips to the village, the envy of the peasants for the much easier, as it seemed to them, life of workers [4, 67].

Negative reviews about the working class were heard at rural gatherings, re-election meetings, and in letters of appeal to periodicals (newspapers) and party-Soviet structures. As for the latter, letters of appeal to the central authorities are vivid evidence of the dissatisfaction of the Ukrainian peasantry with the working presence in the countryside. Corresponding correspondence addressed to specific higher party-Soviet leaders of Ukraine, primarily L. Kaganovich, G. Petrovsky and $\mathrm{V}$. Chubar, is characterized by peasant emotionality. In particular, along with despair, powerlessness and anger, she also contains a certain hope to find understanding and support among senior officials in resolving this problem in favor of the peasantry $[4,68]$.

It should be noted that all property categories of the Ukrainian peasantry openly expressed their displeasure at the presence of workers-twenty five in the village. This happened mainly in everyday conversations and was due directly to the organizational and economic transformations in the village $[4,70]$. There were some cases when a wealthy layer of the village actively campaigned against the arrival of workers in their area, drawing the attention of their fellow villagers to the lack of practical benefit from such "city guests" $[12,136]$.

Such a negative attitude of the peasantry towards the workers-bosses often had a very concrete and real basis caused by the self-damaging behavior of the latter. It had such manifestations as: episodic presence, superficial and frivolous campaigning among under the patronage peasants, their drunken state. For example, in particular in one of the profile journals "Patronage questions" quite clearly and directly stated: "The whole company will come to the village in a city clothes, walk, have fun in their pleasure (sometimes may even drink)... and also go noisy back" $[12,137]$.

Often, a sharp criticism resounded to seconded workers, accompanied by calls for the overthrow of the dictatorship of the proletariat. Thus, in the late 1920s, leaflets circulating in rural areas of Ukraine reported: "From abroad (what means other Soviet republics) 8,000 heads of kolkhozes were appointed to Ukraine, there will be a serfdom" [14, 60], "If you do not change your policy, then we will go against the Soviet power, do not think, we are stronger than the workers" $[4,70]$. In the first six months of 1929, 117 different anonymous leaflets with antiSoviet and anti-proletarian content were distributed in rural settlements of Ukraine [4, 70].

The workers sent to the villages had every reason to worry about saving their lives, as often enough they had to face not just the opposition-minded peasantry, but to meet their openly hostile armed resistance $[14,61]$. In general, taking together the main types of anti-Soviet and directly anti-worker manifestations in the countryside, Ukraine ranks second place among the "unreliable" areas in the Ukrainian SSR: 73 mass actions and 256 terrorist attacks [4, 65]. For example, according to the OGPU (United State Political Administration), the number of terrorist acts against lower-level party-unit staff and rural activists in Ukraine increased exponentially in 1929: in January - 43, and in May - 99 [4, 64]. So, one of the worker brigades, arriving in December 1929 in Glushkivtsi village of the Proskuriv district (present-day Khmelnytsky oblast) and after hearing a number of threats to their address from local residents, inspired by the previous beating of representatives of the poor committee, the grain-harvesting commission and rural activists, hurriedly left the settlement $[14,60]$. In addition to the above-mentioned types of struggle against undesirable seconded workers, there were also such as: provocations, arsons, rumors, emigration sentiments, etc. $[4,78]$. The Ukrainian peasantry did not change its point of view even during the Holodomor-genocide, pointing to the "arriving assistants of the working professions" as an "alien element in the countryside" $[15,146]$.

But, for the sake of justice, it should be noted that the rejection of the proletariat by the Ukrainian peasantry was not absolute. In the rural society, people who attributed urban workers to the category of "not a friend but not a foe" met, considering their own disorder as a result of the policy of the party-Soviet leadership and did not associate it directly or indirectly with the proletarians because they believed that the worker class who, since the establishment of Soviet power in Ukraine, was completely dependent on it, became a victim of circumstances and was 
therefore forced to participate in the deprivation of the peasantry of economic independence [16, 11]. Apparently, Ukrainian peasants had a bigger volume of information about the worker environment, whose representatives were also known to be dissatisfied with their standard of living in various forms.

The presence of seconded workers in rural settlements of Ukraine, within the specified period, had practical consequences: effective, meaningful influence on the consciousness of the peasantry, its cultural and spiritual preferences, rather moderate position of the majority of peasants regarding the proletariat (their way of life and way of thinking) has undergone dramatic changes as a result of the establishment of a state farm - kolkhoz system in the Ukrainian countryside [17, 259], in particular the spread of "proletarian culture" in the Ukrainian countryside has led to a devaluation of the peasantry, the assertion of incivility, and the decline of social morality [10, 71].

"Appointees" is another contingent who was also assigned to the category of "strangers" by the Ukrainian SSR peasantry during the relevant period of the interwar time. Establishing and maintaining of rigid state control over the rural population in the political and socio-economic fields of their life did not do without the layer of executors of the will of the Bolshevik leaders staff of the grassroots party-Soviet apparatus in the countryside. Since the first years of the establishment of Soviet power in Ukraine, senior party-state leadership has seriously taken care of its creation and quality functioning, as the responsible local authorities and local selfgovernment have been entrusted with the responsible mission - to implement the idea of building a "socialist agricultural production" [17, 263].

The rejection of the appointees by the Ukrainian peasantry was due to the hostility they felt to the top decisions and candidates. The Soviet leadership offered an alternative to the Ukrainian peasantry to vote in advance of pre-made lists of communists and sympathizers without prior discussion with voters about the nominees [18, 41-42]. In this way it sought to strengthen its influence on the institute of peasant self-government through local elections $[19,265]$. The situation with the appointment of the heads of the kolkhozes, which received the corresponding position mostly on the recommendation of the district unit of the $\mathrm{CP}(\mathrm{b}) \mathrm{U}$ and the district executive committee, was not better [19, 268].

Such reluctance or inability of the Soviet authorities to establish a constructive dialogue with the Ukrainian peasantry in the interwar period has sometimes led to the replacement of the principle of election by appointment (imposition of candidates), which, in turn, enabled the communists and Komsomol members to elect "themselves" into the governing bodies of rural territories [17, 272].

During this period, the party-Soviet leadership tried through appointments (workers, office workers, teachers, students, soldiers, the local poor) to fill the cadre structure of local authorities with "conscious" executors of political and economic campaigns of the Soviet government in the countryside $[17,273]$. An important criterion applied to candidates for vacant positions in peasant self-government and kolkhozes was adherence to Soviet power [14, 61].

The proper system of functioning of the grassroots party-Soviet apparatus - rigid administrative pressure and strict adherence to the class-ideological principle - not only actually eliminated the Ukrainian peasantry from participating in the elections, but also led to the cleansing of the rural authorities from the "politically unreliable" element. For example, in the Chernihiv region in 1933, 215 people were classified as such [17, 274-275].

Instead of "purified communists", tens of thousands of communists were sent to rural Ukraine from large industrial centers of the USSR, who filled almost (90\%) vacant positions in local governments and kolkhozes $[20,51]$. Such an imbalance of the social composition of rural party cells, in which the "outsiders", namely "non-locals" clearly prevailed, led to the detachment of the grassroots party-Soviet apparatus from the rural society and helped to preserve the negative reaction of the Ukrainian peasantry to the activities of local party members [21, 59].

The existing staff reserve led to the alienation of the "appointees" from the main peasant mass, despite even their personal qualities. The peasants believed that they were removing worthy people, appointing in their place unskilleds, those who could not find access to the villagers [17, 275]. The situation was further exacerbated by the fact that in the event of the inability of the 
"appointee" to perform his job qualitatively, the question of his dismissal from the position was solved only with the consent of the organization that sent him [14, 62].

Such circumstances contributed to the fact that the top party-state leadership of the USSR and Ukraine, as well as to the editions of periodicals, received letters-appeals with statements such as: "We did not choose them", "They are strangers", "They appoint people, without asking us" [16, 14].

The majority of the Ukrainian peasantry of the first five-year plan opposed the communists assigned to their villages also because the urban (so - stranger, "alien") staff of many rural party cells in them influenced the local authorities for the most part through administration and intimidation. In addition, with little experience in practical work, appointees often made serious mistakes during the complete collectivization and economic activity of kolkhozes [22, 379].

In this context, it is worth paying attention to the immediate reasons for the removal of the rural society from the party members and its desire to eliminate the "appointees" from participating in rural management. The command-administrative methods of agricultural management, the ideological obsession of the Bolsheviks, their desire to destroy the traditional worldview foundations of the Ukrainian peasantry, which they considered "petty bourgeois", and to impose on it the Soviet ideological and value orientations - it was the main thing that pushed the multimillion peasant masses away from the $\mathrm{CP}(\mathrm{b}) \mathrm{U}[23,127]$.

Equally indignant in the peasant environment was the issue of nomination by the Bolsheviks for leadership positions in local executive bodies of farm laborer and rural poor [24, 57]. It also caused a flurry of criticism from the majority of the Ukrainian SSR peasantry and even became subject to ridicule and reproach, as poverty in the Ukrainian rural society was traditionally associated with "parasites" and "idleness" $[25,13 ; 21,62]$. To the rural lumpen were enrolled the members of the rural community who could not and did not wish, according to the peasants, to work on the land $[26,101]$. Moreover, the sharp rejection of local activists by the Ukrainian peasantry was prompted by their conviction that these people were outside the peasant outlook space (manifestation of marginal and criminal behavior - participation in collectivization, dekulakization and deportation) [17, 282].

It should also be noted that objects of xenophobia in different groups and individuals may vary. This means that some representatives of the Ukrainian peasantry could oppose themselves to other categories of "strangers" not mentioned in this publication. Consolidatedly, as noted above, they opposed the seconded workers, appointees, as well as local Bolsheviks and rural activists, whom the Communist Party and the Soviet government sought to use to achieve their great goals, but without taking into account the interests and needs of the entire rural community.

The specific style of communication, behavior and interaction with other strata inherent in the Ukrainian peasantry, as well as within this phenomenon of its desire to protest against unpopular power in the countryside, was manifested in a combination of various forms of xenophobia, such as: active, passive, skillfully disguised, attributed or supposed opposition. The forms of expression of xenophobia in relation to the aforementioned "another's" were quite diverse, which allows them to be classified into verbalized and nonverbalized ones [27, 239].

Based on the thesis that xenophobia carriers and leaders are, above all, those strata and groups who feel the threat to their social identity and are afraid of subordination and absorption by more powerful powers [1], one of the factors that contributed to the emergence of frontal opposition of the Ukrainian rural society to stranger elements should be considered the partystate policy of the Bolsheviks against peasants-independent farmers in the conditions of continuous collectivization.

In the reflections of the Ukrainian peasants, the analogy between the Soviet and the old authorities with its former orders in the countryside was often drawn (the peasants Ukrainian SSR discussed the question of which is better: tsarism or Bilshovism?) [20, 54; 28, 93; 29, 48], and although the benefits of the past are not observed, too close and well known this past was, the fact of comparison emphasizes the burden of real, no improved socio-economic status of the countryside after a decade of Soviet rule in Ukraine.

Such criticism from the point of view of the Ukrainian peasant was absolutely objective and fair, for in assessing his existence and analyzing the measures taken by the Soviet authorities in 
relation to the countryside, he proceeded primarily from ideas of material good for himself and his family, and not from the position of state interests. In other words, in this case, we are dealing with a pronounced peasant ego-centrism and a social-psychological setting on the perception of his economy as a dominant, self-sufficient unit.

Another factor that contributed to the formation of alienation of the Ukrainian peasantry in relation to the above categories of persons was its affiliation with the local community (land community - until 1930, village council - since 1930) [30]. For example, the characteristic features of the pre-collective farm stage of the Soviet period in the history of Ukraine (as, incidentally, the previous period) were conservatism in views and food self-sufficiency. The localism of the peasant world in the conditions of post-war devastation and increased pressure from the state again made itself known, appearing to be a natural and adequate defensive reaction, and opposed the Bolshevik course to obtain all fields of public life. As we know, the Bolsheviks, for the first decade in their being in power in Ukraine, sought and, eventually, found an effective but devastating way for the Ukrainian countryside to combat rural localism and the rural society itself - complete collectivization.

Conclusions. Examining the problem of "The manifestations of xenophobic sentiments of the peasantry of the Ukrainian SSR during the complete collectivization" the author came to the conclusion that the Ukrainian peasantry divided people according to the degree of belonging to the local community: "foes" and "friends". Since peasant self-government was an institution of socialization of an individual, the peasant confronted the outside world not as a separate individual, but through the appropriate organization. From an early age he perceived as unshakable laws of nature the order, customs and traditions of his community, so their obvious violation by the Soviet authorities during the second "communist assault" gave rise to rejection by the peasantry of the Ukrainian SSR as a policy of continuous collectivization, and those who pursued it on the ground.

\section{Список використаної літератури}

1. Енциклопедія прав людини : соціально-педагогічний аспект : [колективна монографія] / кол. авт., за заг. ред. проф. Н. А. Сейко. - 2014. - Режим доступу: http://eprints.zu.edu.ua

2. Гук Ю. Особливості розгортання конфлікту у різних сферах суспільства: етичний аспект / Ю. Гук // Вісник Львівського університету Філософські науки. - 2007. - № 10. - С. 192-200.

3. Історія українського селянства: Нариси: В 2 т. Т. 2. / О. Андрощук, В. Баран, О. Веселова та ін. / В. Смолій (відп. ред.). - Київ : Наук. думка, 2006. - 653 с.

4. Георгізов Г. М. Українське селянство доби непу: динаміка політичних настроїв та свідомості / Г. М. Георгізов. - Черкаси : ФОП О. Ф. Нечитайло «Поліграфічний центр», 2016. - 133 с.

5. Москаленко В. Г. Формування основ загального виборчого права в УРСР: політико-правовий аспект (20-30-і рр. XX ст.) / В. Г. Москаленко // Література та культура Полісся. - 2009. № 49. - С. 17-26.

6. Спик Л. І. Динаміка соціально-політичних настроїв робітничого класу України під час політики «українізації» (1923-1938рp.) / Л. І. Єпік // Збірник наукових праць Харківського національного педагогічного університету імені Григорія Сковороди. - Серія: Історія та географія. - 2013. Вип. 47. - С. 13-20.

7. Гончарова Н. П. Соціально-економічні відносини між містом і селом в роки непу: сучасна історіографія. - 2008. - Режим доступу: http://www.irbis-nbuv.gov.ua.

8. Лозовий В. С. Сприйняття селянством більшовиків та радянської влади у період Директорії УНР / В. С. Лозовий // Український селянин. - 2010. - № 12. - С. 92-95.

9. Вовк О. Преса української еміграції як джерело вивчення культури, освіти та повсякденного життя українців (1920-ті роки) / О. Вовк // Педагогічні науки: теорія, історія, інноваційні технології. - 2019. - № 6(90). - С. 210-226.

10. Петренко В. І. Більшовицька влада та українське селянство: репресії «буксирних» бригад на Поділлі у 1929-1933 pp. / В. І. Петренко // Наукові записки Вінницького державного педагогічного університету ім. М. Коцюбинського. - Серія: Історія. - 2019. - № 27. - С. 67-74.

11. Фільваркова А. В. Хлібозаготівельна політика і основні методи управління тоталітарного режиму / А. В. Фільваркова // Наукові записки Вінницького державного педагогічного університету імені Михайла Коцюбинського. - Серія: Історія. - 2010. - № 18. - С. 99-103.

12. Тростогон А. М. Деякі аспекти розвитку взаємовідносин українського міста і села в 1920 -і рр. / А. М. Тростогон // Наукові записки Вінницького державного педагогічного університету імені Михайла Коцюбинського. - Серія: Історія. - 2000. - № 2. - С. 135-139. 
13. Кульчицький С. Червоний виклик. Історія комунізму в Україні від його народження до загибелі / С. Кульчицький. - Кн. 2. - Київ: Темпора, 2013. -628 с.

14. Вовк О. Використання комуністичною владою міських робітників для радянізації українського села (1920-ті рр.) / О. Вовк // Емінак. - 2018. - № 4(1). - С. 55-62.

15. Васильєв В. Ю. Селянський опір колективізації в Україні (1930-ті рр.) / В. Ю. Васильєв // Історія України. Маловідомі імена, події, факти. - Київ : Ін-т історії України. - 2005. Вип. 31. - С. 140-150.

16. Данільєва Ю. Г. Співіснування сільської та міської культур радянської України в контексті повсякденності (20-30-і роки XX століття): автореф. дис... канд. іст. наук / Г. Ю. Данільєва. Луганськ, 2012. - 19 с.

17. Лисенко О. Сільські активісти Чернігівщини (кін. 1920-1930-ті pр.): типологія поведінки / О. Лисенко // 3 архівів ВУЧК-ГПУ-НКВД-КГБ. - 2013. - Вип. (1-2). - С. 255-284.

18. Бурда В. Абсентеїзм у виборчих компаніях до місцевих рад УСРР у 1920-ті pp. / В. Бурда // Часопис української історії. - 2016. - Вип. 33. - С. 40-47.

19. Кульчицький С. В. Комунізм в Україні: перше десятиріччя (1919-1928) / С. В. Кульчицький. Київ: Основи, 1996. - 396 с.

20. Єфіменко Г. Г. Національні аспекти у формуванні компартійно-радянського апарату в УРСР (1932-1938) / Г. Г. Єфіменко // Український історичний журнал. - 2000. - № 6. - С. 51-66.

21. Тригуб П. Агробази як організаційна форма державного сільськогосподарського підприємства на Миколаївщині в роки нової економічної політики (на прикладі агробази імені Чубаря) / П. Тригуб. // Емінак. - 2010. - № 1-4. - С. 58-66.

22. Советская деревня глазами ВЧК-ОГПУ-НКВД. 1918-1939. Документы и материалы. В 4-х т. Т. 3. 1930-1934 гг. Кн.1. 1930-1931 гг. / А. Берелович, В. Данілов (ред.). - Москва : Российская политическая энциклопедия (РОССПЭН), 2003. - 864 с.

23. Рубан В. «Бийте у дзвони»: настрої та поведінка селянства Поділля наприкінці 1920-х - початку 1930-х рр.: у документах ДПУ УСРР / В. Рубан // 3 архівів ВУЧК-ГПУ-НКВД-КГБ. - 2018. № 2(50). - С. 123-136.

24. Данільєва Ю. Г. Повсякденне життя селян радянської України у 20-30-і роки XX ст. / Ю. Г. Данільєва // Українське радянське суспільство 30-х рр. ХХ ст.: Історичні записки. 2010. - Вип. 25. - С. 56-60.

25. Сухонос В. В. Радянська модель місцевого управління доби воєнного комунізму: конституційноправовий аспект / В. В. Сухонос // Правові горизонти. - 2019. - № 14(27). - С. 7-15.

26. Іріоглу Ю. О. Явище насильства в структурі селянських усних наративів Північного Приазов'я / О. Ю. Іріоглу // The Oriental Studies. - 2017. - № 79. - С. 92-127.

27. Борейчук I. О. Соціально-психологічні детермінанти явища ксенофобії: історико-теоретичний аспект / I. О. Борейчук // Проблеми політичної психології та її роль у становленні громадянина Української держави. - 2009. - Вип. 9. - С. 236-245.

28. Сливенко В. А. Роль органів ДПУ в репресивному механізмі хлібозаготівельних кампаній в УСРР у 1927-1929 рр. (за матеріалами Півдня України) / В. А. Сливенко // Український селянин. - 2017. - № 17. - С. 92-95.

29. Реабілітовані історією: наук.-док. серія кн.: у 27 т. Черкаська область. Кн. 9 / Солдатенко В. Ф. (Ред.). - Черкаси : Інтроліга ТОР, 2016. - 640 с.

30. Мацюцький В. М. Діяльність земельної громади Лівобережної України в соціальній сфері (1922-1930 pp.) / В. М. Мацюцький. - Режим доступу: http://journals.hnpu.edu.ua/index.php/ hisgeo/article/view/2642.

\section{References}

1. Seiko, N. (ed.). (2014). Encyclopedia of human rights: socio-pedagogical aspect: Access mode: http://eprints.zu.edu.ua/23741/1/\%D0\%A1\%D0\%B5\%D

2. Guk, Yu. (2007). Features of the development of conflict in various areas of society: ethical aspect. Acta Universitatis De Scientiarum in Leopolis (Bulletin of the Lviv University Philosophical Sciences), 10, pp. 192-200 [in Ukr.].

3. Smoliy, V. A. (ed.). (2006). History of the Ukrainian peasantry. (In 2 vols. Vol. 2). Kiev: Scientific opinion [in Ukr.].

4. Georgizov, G. M. (2016). The Ukrainian peasantry of the NEP period: the dynamics of political sentiment and consciousness. Cherkasy: FOP A. F. Nechitaylo "Printing Center" [in Ukr.].

5. Moskalenko, V. G. (2009). Formation of the foundations of universal suffrage in the USSR: the political and legal aspect (20-30s of the twentieth century). Litterae et cultus ex Polesye (Literature and Culture of Polesie), 49, 17-26 [in Ukr.]. 
6. Epik, L. I. (2013). The dynamics of the socio-political moods of the working class of Ukraine during the policy of "Ukrainization" (1923-1938). Paedagogicae National University of scientific papers collectio ex Kharkov Grigory Skovoroda eius nomine nuncupetur. Subjects: Geography, et historia (Collection of scientific papers of the Kharkov National Pedagogical University named after Grigory Skovoroda. Series: History and Geography), (47), 13-20 [in Ukr.].

7. Goncharova, N. P. (2008). Socio-economic relations between the city and the village during the NEP: modern historiography. Access mode: http://www.irbis-nbuv.gov.ua [in Ukr.].

8. Lozovoy, V. S. (2010). Perception by the peasantry of the Bolsheviks and Soviet power during the Directory of the Ukrainian People's Republic. Peasant Ucraina (Ukrainian Peasant), 12, pp. 92-95 [in Ukr.].

9. Vovk, O. (2019). The press of Ukrainian emigration as a source of studying the culture, education and everyday life of Ukrainians (1920s). Paedagogicae scientiae doctrina, historia, technologiae innovative (Pedagogical sciences: theory, history, innovative technologies), 6(90), pp. 210-226 [in Ukr.].

10. Petrenko, V. I. (2019). Bolshevik power and the Ukrainian peasantry: repression of the "towing" brigades in Podillia in 1929-1933 Scientific notas Vinnitsa de re publica University paedagogicae Mikhail Kotsyubinsky eius nomine nuncupetur: serie Historia (Scientific notes of Vinnitsa State Pedagogical University named after Mikhail Kotsyubinsky. Series: History), 27 pp. 67-74 [in Ukr.].

11. Filvarkova, A. V. (2010). Bread procurement policy and basic management methods of a totalitarian regime. Scientific notas Vinnitsa de re publica University paedagogicae Mikhail Kotsyubinsky eius nomine nuncupetur: serie Historia (Scientific notes of Vinnitsa State Pedagogical University named after Mikhail Kotsyubinsky. Series: History), 18, pp. 99-103 [in Ukr.].

12. Trostogon, A. M. (2000). Some aspects of the development of relations between the Ukrainian city and village in the 1920s. Scientific notas Vinnitsa de re publica University paedagogicae Mikhail Kotsyubinsky eius nomine nuncupetur: serie Historia (Scientific notes of Vinnitsa State Pedagogical University named after Mikhail Kotsyubinsky. Series: History), 2, pp. 135-139 [in Ukr.].

13. Kulchitsky, S. (2013). Red call. The history of communism in Ukraine from its birth to death (Vol. 1). Kiev: Tempor [in Ukr.].

14. Vovk, O. (2018). The use of urban workers by the communist government for the sovietization of the Ukrainian village (1920s). Eminak (Eminak), 4(1), pp. 55-62 [in Ukr.].

15. Vasiliev, V. Yu. (2005). Peasant resistance to collectivization in Ukraine (1930s). Historia de Ucraina. Little-known nomina, certe facta (History of Ukraine. Little-known names, events, facts), (31), 140150 [in Ukr.].

16. Danilieva, Yu. G. (2010). Everyday life of the peasants of Soviet Ukraine in the 20-30s of the XX century. Ucraina Soviet de 30 Societas XX century: Historical Notes (Ukrainian Soviet society of the 30s. XX century.: Historical notes), (25), 56-60 [in Ukr.].

17. Lysenko, O. (2013). Rural activists of the Chernihiv region (late 1920s - 1930s): typology of behavior. Ex archives VUChK-GPU-NKVD-KGB (From the archives of VUChK-GPU-NKVD-KGB), (1-2), 255-284 [in Ukr.].

18. Burda, V. (2016). Absenteeism in election campaigns in local councils of the USSR in the 1920s. Journal de Ucraina historia (Journal of Ukrainian History), (33). 40-47 [in Ukr.].

19. Kulchitsky, S. V. (1996). Communism in Ukraine: the first decade (1919-1928). Kiev: Basics [in Ukr.].

20. Efimenko, G. G. (2000). National aspects in the formation of the Communist Party-Soviet apparatus in the Ukrainian SSR (1932-1938). Ucraina historical Journal (Ukrainian Historical Journal), 6, pp. 51-66 [in Ukr.].

21. Trigub, P. (2010). Agrobase as an organizational form of the state agricultural enterprise in Nikolayevshchina during the years of the new economic policy (on the example of the Agrobaz named after Chubar). Ermak (Ermak), 1-4. pp. 58-66 [in Ukr.].

22. Berelovich, A., Danilov, V. (ed.). (2003). Soviet village through the eyes of the ChEKA-OGPUNKVD. 1918-1939. Documents and materials (in 4 vols. T. 3. 1930-1934; Book 1. 1930-1931). Moscow: Russian Political Encyclopedia (ROSSPEN) [in Russ.].

23. Ruban V. (2018). "Hit the bells": the mood and behavior of the peasantry of Podillia in the late 1920 s - early 1930s: in the documents of the GPU of the Ukrainian SSR. Ex archives VUChK-GPUNKVD-KGB (From the archives of VUChK-GPU-NKVD-KGB), 2(50), 123-136 [in Ukr.].

24. Danilieva, Yu. G. (2010). Everyday life of the peasants of Soviet Ukraine in the 20-30s of the XX century. Ucraina Soviet de 30 Societas XX century: Historical Notes (Ukrainian Soviet society of the 30s. XX century.: Historical notes), (25), 56-60 [in Ukr.].

25. Sukhonos, V. V. (2019). The Soviet model of local government during the period of war communism: constitutional and legal aspect. legalis prospectu orientes (Legal Horizons), 14(27), pp. 7-15 [in Ukr.].

26. Irioglu, Yu. O. (2017). The manifestation of violence in the structure of the rural peasant population of the Pryvny Priaz's. Orientales studios (The Oriental Studies), 79, pp. 92-127 [in Ukr.]. 
27. Boreychuk, I. A. (2009). Socio-psychological determinants of the phenomenon of xenophobia: historical and theoretical aspect. Psychologia et de politica partes suas difficultates et ponderis ad Ucraina in re publica civis (Problems of political psychology and its role in becoming a citizen of the Ukrainian state), (9), 236-245 [in Ukr.].

28. Slivenko V. A. (2017). The role of GPU organs in the repressive mechanism of grain procurement campaigns in the Ukrainian SSR in 1927-1929 (Based on materials from the South of Ukraine) Peasant Ucraina (Ukrainian peasant), 17, pp. 92-95 [in Ukr.].

29. Soldatenko V. F. (Ed.). (2016). Rehabilitated by History: Scientific Doc. series of books: in $27 \mathrm{t}$. Cherkasy region. (In 27 vol. Book 9). Cherkasy: Introliga TOP [in Ukr.].

30. Matsyutky, V. M. (2019). Activities of the land community of the Left Bank of Ukraine in the social sphere (1922-1930). Access mode: http://journals.hnpu.edu.ua [in Ukr.].

МОТУЗ Валерія Костянтинівна, кандидат історичних наук, старший викладач кафедри археології та спеціальних галузей історичної науки Черкаського національного університету імені Богдана Хмельницького,

e-mail: v.k.motuz@ukr.net

\section{ПРОЯВИ КСЕНОФОБСЬКИХ НАСТРОЇВ СЕЛЯНСТВОМ УКРАЇНСЬКОЇ СРР ПІД ЧАС СУЦІЛЬНОӤ КОЛЕКТИВІЗАЦЇ̈}

Радянська соиіальна політика в сільській місиевості Української СРР у 1929-1933 рр. визначалася доктриною, щзо створювала механізм політичної заданості практичних дій відносно селянства у напрямку перетворення дрібного приватного власника у сільського пролетаря. Практичні реалії українського села зазначеного періоду, особливо ті, щзо стосувались економічних відносин, стали причиною прояву ксенофобських настроїв селянством Української СРР. Саме в ией радянський період історії Украӥни селянство відзначилось активністю у відстоюванні інтересів своєї громади, направленою на боротьбу з неприйнятними для більшості нововведеннями та їх втілювачами.

Члени соиіуму/громади на різних етапах свого розвитку схильні сприймати та оцінювати життєві явища крізь призму базових иінностей та традиџій власної групи, яка виступаєяк стандарт або норма: «ми» («свої») краще, ніж «вони» («чужі»). У иьому випадкупід «ми» розумісмо селянство Украӥнської СРР у період проведення суцільної колективізації (1929 - 1933 рр.). Це поняття буде розглянуто з позииї його приналежності до відповідної соціальної категорії, консервативного інституту - селян-власників (вільних господарів), тобто, йдеться про історично сформовану в український сільській місиевості організаційно-правову форму індивідуального користування землею та місиевого самоврядування. Під словом «вони» - всі ті, хто не вписувався у відповідний формат і сприяв остаточному викоріненню з українського села одноосібництва та насадженню у ньому колективізму. У більшості випадків це люди, які не мали безпосереднього відномення до сільської спільноти. Інакше кажучи, суб'єктом ксенофобії в сільському соиіумі Української СРР у 1929 - 1933 рр. в основному були ті селяни, які підпали під прямий або опосередкований тиск $з$ боку радянської влади, а об'єктом - виступили ї̈ представники, які безпосередньо чинили ией тиск, - двадиятип 'ятитисячники, призначенці та сільські активісти.

Форми прояву ксенофобії селянством Української СРР у 1929 - 1933 рр. були вербалізовані та невербалізовані. До першої відносились: привселюдна критика кандидатів на різні посади в місиеві органи влади, відстоювання своїх конституиійних і громадянських прав, висування антирадянських гасел, листи-скарги в газети та до вищого партійно-державного керівництва, протести і т. ін. До другої-ухиляння від голосування або скасування його підсумків, зрив сільських зборів або навмисне затягування часу їх проведення, використання різних методів тиску на владу, погрози фізичною розправою ї̈ представникам тощяо.

В украӥнській історіографії заявлена тема, будучи складником насамперед таких досліднищьких проблем, як суспільно-політичні настрої та культура повсякдення українського селянства, представлена фрагментарно. По суті спостерігаємо відсутність досліджень, в яких за мету було б поставлено реконструкцію прояву ксенофобських настроїв в сільському соиіумі Украӥнської СРР періоду проведення суиільної колективізаиії, щзо й спонукало автора до написання u̧iё статmi.

Ключові слова: суцільна колективізація, селянство УСРР, ксенофобія, двадиятип 'ятитисячники, призначениі, сільські активісти. 